\title{
Comparing the reduction of poverty rate between China and Gabon through One Belt and Road Project
}

\author{
Pamela Nguembi *, Yanrong Zhang *, \\ Haider Salaheldeen Abdalla ** \\ * College of Financial and Economics, Gansu Agricultural University, \\ Lanzhou City, Gansu Province, 73000, China \\ ** Agricultural Research Corporation, Ad-Damer, Sudan
}

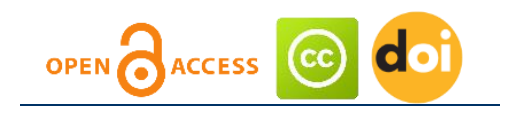

Article history:

Received: May 25, 2020

1st Revision: August 26,

2020

Accepted: October 31,

2020

JEL classification:

C58

E44

N17

DOI:

10.14254/jems.2020.5-2.9

\begin{abstract}
The value of economic development and reduction poverty has been at the fore-front research in many countries. However, little is thought about both China-Gabon. Data were collected employing a survey questionnaire approach to a sample of 210 financial sectors in China and Gabon. The results regarding Gabon show that governance reform can bring significant macro-financial benefits. Additionally, the results proposed that financial development significantly influence poverty reduction. Similarly, the results regarding china show development of monetary sector significantly and positively impacts poverty reduction during which, has been implemented for many years long term. This paper seeks to analyze causality between Gabon. There's an urgent need enhance administration curb corruption order increase domestic income, strengthen public management quality expenditure, business environment, promote investment both private sectors
\end{abstract}

Keywords: Gabon, China, poverty, reduction, financial development, management.

\section{Introduction}

The relation between fiscal growth and poverty reduction has provided much literature from both theoretical empirical perspectives in recent years. Research shows by fostering economic process, finance creation may reduce poverty. The view is accordant with a mechanism called "trickle-down." Preceding supporting trickle-down effect fines (Funke et al, 2005.). Also, some primarily used residual-based co-integration regarding (Engle, et al., 1987) (Johansen Juselius 1990) maximum probability checks long-term reduction. However, when the sample size, simply too small, these strategies will not be sufficient (Narayan et al, 2005; Odhiambo et al, 2009a) China Gabon haven't yet thoroughly examined causality of a developing, governing, fighting corruption, growing, 
domestic income, strengthening economy Section5: presents the debates, implications, bound, and future research, and conclusion.

\subsection{Theoretical background and hypotheses development}

\subsubsection{Financial development}

Economic improvement can lead on to poverty reduction in numerous ways (Odhiambo, 2010 b). Firstly, financial growth will boost opportunities for poor people to access formal finance by reducing the value of lending to small lenders, among other items (Jillian and Kirkpatrick, 2002). Financial development also allows the risk of support them. It should even be remembered that financial success can trickle down through the vulnerable through its effect on the economic process. This is often because of the implied positive relation between financial development and growth, in large part. While financial sector growth contains a direct impact on poverty alleviation, only a few studies have examined the causal path between financial developments. (Jiang, 2004), and (Yan 2006), (Bittencourt, 2010a), (Odhiambo, 2010b), (Geda et al., 2006), (Quartey, 2005), (Burgess \& Pande, 2003 and Hussein, 2004), for instance, when evaluating the potential role of micro-finance for poverty alleviation and financial reform in China, (Park et al., 2004) find that the success of China's micro-finance movement somewhat mixed started in 1994; (Yuan, 2006) examine the efficacy of civilian lending in China's rural poverty structures. The results indicated that civilian loans in China would effectively alleviate rural poverty using the static Grey-relevance and forward-looking, dynamic Grey-relevance matrix. The authors recommend developing both the conventional financial market and the civilian finance sector to efficiently support the war against poverty. The authors also recommend transforming the agricultural economic structure. Analyzing the impact of growth within the financial sector on earnings' inequality in Brazil during the 1980s and also the half of the 1990s, (Bittencourt, 2010) finds that wider access to finance and credit markets have had a significant and robust effect on reducing inequality.

(Odhiambo, 2010a), while analyzing the inter-temporal causal relationship between the expansion of the financial sector and poverty reduction in Zambia using an auto-regressive distributed lag test (ARDL)-bound procedure, finds that the casual linkage between financial development and poverty reduction is tuned in to the proxy wont to evaluate financial growth. (Odhiambo, 2010b) uses a tie-variate causality test to look at the inter-temporal causal association between the financial development of Kenya and therefore the reduction of poverty among.

\subsubsection{Governance reform and financial development}

This time saw rural development, distribution networks, and procurement prices institutional reforms. The elemental shift was reform, marked by introduction of system family understanding responsibility in China, which greatly stirred motivation workplace to interact activity. Reforms have delivered impressive effect from reducing poorness. Their profits per capital rose at a rate 16.5 percent a year. China's official standard poverty, UNDP, (2008) dropped rapidly 250 million. These Periods were the fastest fall incidence poverty from 1978 to 1985 . Chinese government has developed differentiated agencies for focused programs reduce eighty people remained poor in 1994 and down 45 in 1985 (Cammack, 2004. UNDP, 2008). During seven-year (1994-2000), launched 8-7 programs aiming bring much remaining 80 lines. China's anti-poverty upgraded more ambitious national policy stepped up efforts combat as result, number living fallen 1994322000 significant changes balancing improvements development between urban areas across different regions. Compendium on reduction growth (2001-2010) published 2001. China adopted balanced policies create new countryside, improve western central started decrease, 302001152007 (UNDP began implementing reform in late 1970 s than years made substantial progress that regard. Single banking before transformed into complex diversified financial set-up. Finance industry currently includes bank (also known people's China), political commercial banks, insurance companies, non-bank institutions, two stocks markets, bond market. It concentrated mainly four major state-owned namely (BOC), construction (CCB), industrial (ICBC), agriculture (ABC). 1980s. Coastal zone, example, regional had been established; network credit unions set under supervision of agricultural and union established area. Intermediaries, such trust investment firms (tic), operate limited with limits deposit lending sources; these evolved proliferated (Allen et al., 2005). Gao, (2010), was 
mentioned that since (2001-2010) China began implementing economic reform. However, within the late 1970s and for over 30 years it has made substantial progress there in regard. The one industry before the reform was transformed into a more complex and diversified economic system. The finance industry currently includes the financial organization (also called the People's Bank of China). It policies were to:

1) Establishment of three policy banks, including national development bank, China agricultural bank, and China export-import bank.

- $\quad$ Turning urban credit cooperatives into commercial banks 1996-1998.

- Licensing non-state banks.

- Licensing international

- Government intervention distribution credit.

- Loosening interest rate regulation.

Despite recent efforts, weaknesses governance Gabonese Republic promoting development. Existing gap implementing their successful implementation why have not resulted sustainable economy payouts. Reform Gabon can, however, positive effect on financial Gabon. (Fig. 1).

The Hypothesis:

1a: Governance reform may positively impact financial development in Gabon.

1b: Governance reform may positively impact financial development in China.

In fact, the republic of Gabon still faces considerable challenges to growth. A major natural resources' endowment has enabled Gabon to become one in every of the wealthiest countries in Africa, with GDP per capital greater than \$7, 500 in 2018. However, all parts of the society also need like economic development, third people living below poverty level and a percent more than quarter juveniles. Narrow base, weak governance, corruption, inefficient institutions, unattractive business environment are key achieving sustainable inclusive authorities have initiated ambitious reform agenda tackle these problems, improve eradicate corruption. Improving governance is core pillar 2010 strategic development plan (PSGE) authorities,

(2) That in recent years been cornerstone of their growth policies. The main measures include:

Incrimination corruption offenses through legal code, criminalizes numerous crimes related (e.g., passive active bribery; embezzlement misappropriation property by public officials for parties, abuse functions), revitalization national commission combating illicit enrichment (CNL, created 2004,) adoption procurement act 2012: and integration into framework regions. Poor policy changes, compliance rules, insufficient support, and hampered progress. All these make thethirdparty metrics, including subjective expectations, multiple outlets international openness, the World Bank Center highlights attempts to tackle governance.

(3) Vulnerabilities of fiscal institutional acts (tax policy, revenue management, procurement, state-owned enterprises, etc.), restricted collection revenues weighted spending quality efficiency (Dassah, 2013). This reduced space priority expenditure that enhances similarly, high-level poor regulation, broad informal economy continue to dissuade private-sector investment create unequal market playing fields, negatively impacting development. Existing weaknesses ultimately hindered inclusiveness constraining investment, total factor productivity, and human capital. While china's banking sector played critical role fostering financial depth impressive since early 1980s, real money balance exceeded economy. Resident deposits accounted 77.9\% quashing currency 47.2\% m2 2001 (Chen, 2006). Within background steady substantial income growth, opportunities, amount china sustained mid-1980s. So we predicted these:

\section{Hypothesis}

$\mathrm{H}_{2}$ : Financial development has significant and positive impacts on reducing poverty in Gabon. $\mathrm{H}_{3}$ : Financial development impacts China's positively. 
Figure 1: Conceptual model

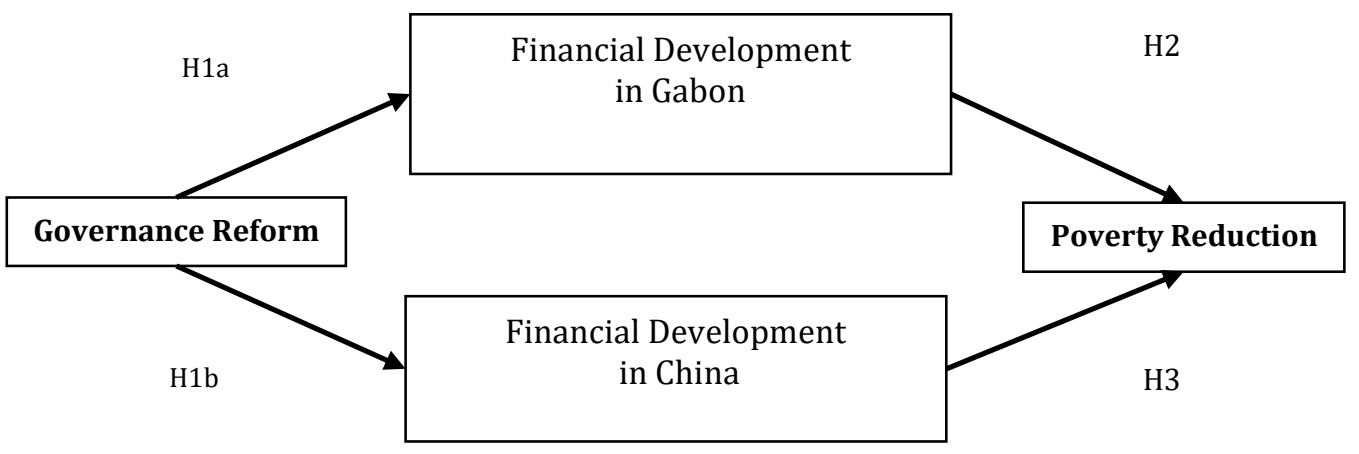

2. Materials and methods

\subsection{Sampling and data collection}

To check our research hypotheses, a survey tool was built to compare poverty alleviation between China and Gabon through One Belt and Road Project. The targeted respondents were required to be financial professionals, managers, and executives with strong financial development skills, as well as poverty reduction knowledge. This method is suitable for studies that aim to test hypotheses, describe populations, develop measurement scales, and establish theoretical models of research (Lee and Shim, 2007). We collected data from a sample of financial sector in China and Gabon. A pilot test comprising 30 participants was underway to verify the respondents understanding of the questionnaire. In addition, two financial industry experts, a scholar, and a fellow researcher reviewed the questionnaire items. We included their suggestions and comments to enhance the understanding of questionnaire items. The pilot test results indicated that no one found any confusion about the questionnaire. From October to December 2019, we initially submitted 800 questionnaires to the financial sector in China and Gabon. After three months, 504 questionnaires were received back and, after deleting the unfilled and unusable questionnaires, we found 210 usable samples with a response rate of 13.72 percent based on the number of companies that were contacted on the phone. Taking into account potential non-response bias, we compared the early and late survey group (Armstrong \& Overtone, 1977).

\subsection{The causality principle}

The development of the theory of knowledge and composition of a solid pillar in classical logic can be achieved by using the causality principle. Using causality we can conclude that something happening regularly will always happen. When a study has comprehensive information in the situation involved we can successfully applied the causality principle to the cases. Nonetheless, when complication arises and uncertainty comes into tragedy, the principle becomes debatable. The more sophisticated situation of the system, the more information is needed. In conclusion, the causality principle states that all real events necessarily have causes (R. Miguel, 2008).

\subsection{The derivation of the causality}

Causality establishes a univocal relationship between cause and event that can be stated mathematically as follow: $\mathrm{R}(\mathrm{C})=\mathrm{E}$.

In science we often find many types as the above equation; that if $\mathrm{C}$ occurs $\mathrm{E}$ will always observed. So we can drive two poverty reduction equations for both Gabon and China republics as follows:

$$
\begin{aligned}
& R(G R+F D G)=E(P R) \\
& R(G R+F D C)=E(P R)
\end{aligned}
$$

where GR=Governance reform, FDG=Financial development in Gabon, FDC=Financial development in China, and $\mathrm{PR}=$ Poverty reduction. 
The results show that this study did not present a major issue with non-response bias. Examination of the single-factor test of specific process bias by Harmon (Podsakoff et al., 2003) revealed eight unlike factors of or similar to 1.0, suggesting a total variance between 70.2 percent. The initial factor showed 30.3 percent of the variance, not the greater part of the overall variance. Therefore, typical process bias (CMB) was not a critical issue in our study. The demographic survey results are shown in (Table 1 ).

\begin{tabular}{lcc} 
Table 1: Sample demographic $(\mathbf{n = 2 1 0})$ & $\mathbf{N}$ & Percent (\%) \\
\hline Characteristics & 11 & 14.2 \\
\hline Agriculture & 13 & 15 \\
E-commerce & 9 & 4.1 \\
Logistics & 14 & 28 \\
Electronic devices & 10 & 14 \\
Woods & 9 & 7 \\
Beverage & 11 & 17.7 \\
Financial & & \\
Organization size (Employees) & 13 & 36.4 \\
1-99 & 12 & 35.7 \\
100-280 & 12 & 27.9 \\
$280-399$ & & \\
Organization age (Year) & 19 & 24.2 \\
<5 years & 13 & 36.4 \\
5-11years & 10 & 26.6 \\
11-25 years & 9 & 12.8 \\
Total assets & 9 & \\
RMB 5-15M & & 36.7 \\
RMB 15-25M & 16 & 28.2 \\
RMB 25-60M & 19 & 35.1 \\
\hline
\end{tabular}

\section{Results}

\subsection{Measurement model}

To test the validity of the measurements we employed confirmatory factor analysis (CFA). The findings are shown in Appendix 2 and Table 2. The reliability of the measurements was measured for the composite reliability values, and the $\alpha$ value of Cronbach all surpassed the 0.7 thresholds, suggesting good reliability (Hair et al., 2010).

\section{Table 2: Reliability and validity analyses}

\begin{tabular}{lccc} 
& Cronbach's a & CR & AVE \\
\hline Governance reform & .89 & .91 & .87 \\
Financial development in Gabon & .90 & .77 & .90 \\
Financial development in China & .87 & .83 & .76 \\
Poverty reduction & .79 & .85 & .92 \\
\hline
\end{tabular}

${ }^{*} \mathrm{CR}$, composite reliability, AVE average variance extracted

As shown in Table 2, AVEs square roots are all higher than the correlations that confirm our measure's discriminating validity (Fornell \& Larcker, 1981).

Table 3: Correlation matrix, means, and standard deviations

\begin{tabular}{lcccccc} 
Constructs & Mean & SD & $\mathbf{1}$ & $\mathbf{2}$ & $\mathbf{3}$ & $\mathbf{4}$ \\
\hline Governance reform & 4.51 & .44 & .84 & & & \\
Financial development in Gabon & 4.18 & .58 & .47 & .90 & & \\
Financial development in China & 4.13 & .52 & .45 & .16 & .81 & .83 \\
Poverty reduction & 4.14 & .56 & .42 & .22 & .47 & .82 \\
\hline
\end{tabular}

*Factors within diagonal (in bold) are square roots of AVE.SD, standard deviations $\mathrm{P}<0.05$, $* * \mathrm{p}<0.01$. 
The measuring model indicated the correct fit for the data (Table 4).

After the measurement model was accepted, we switched the measurement model into a structural model to validate the structural model and the proposed hypotheses.

\subsection{Hypothesis testing}

The majority of the findings in this paper are well established. Accordingly, financial development in Gabon is significantly linked to the reform of governance $(\beta=0.25, p<0.01)$, Hence, $\mathrm{H} 1 \mathrm{a}$ accepted. Reform of governance has an important and positive contact on China's financial growth $(\beta=0.39, \mathrm{p}<0.01)$, thus H1b accepted. However, the findings show that the effect of Gabon's financial development $(\beta=0.04, p=0.31)$ on poverty reduction was not significant and therefore $\mathrm{H} 2$ was rejected. While the effect of financial development in China $(\beta=0.17, p<0.01)$ has a strong and positive effect on poverty reduction, $\mathrm{H} 3$ has therefore been accepted (Table 4 ).

Fig. 2 demonstrates the effect of the restructuring of the governance of financial developments in both Gabon, financial developments and China, on poverty reduction.

Figure 2: Results of the hypothesized model

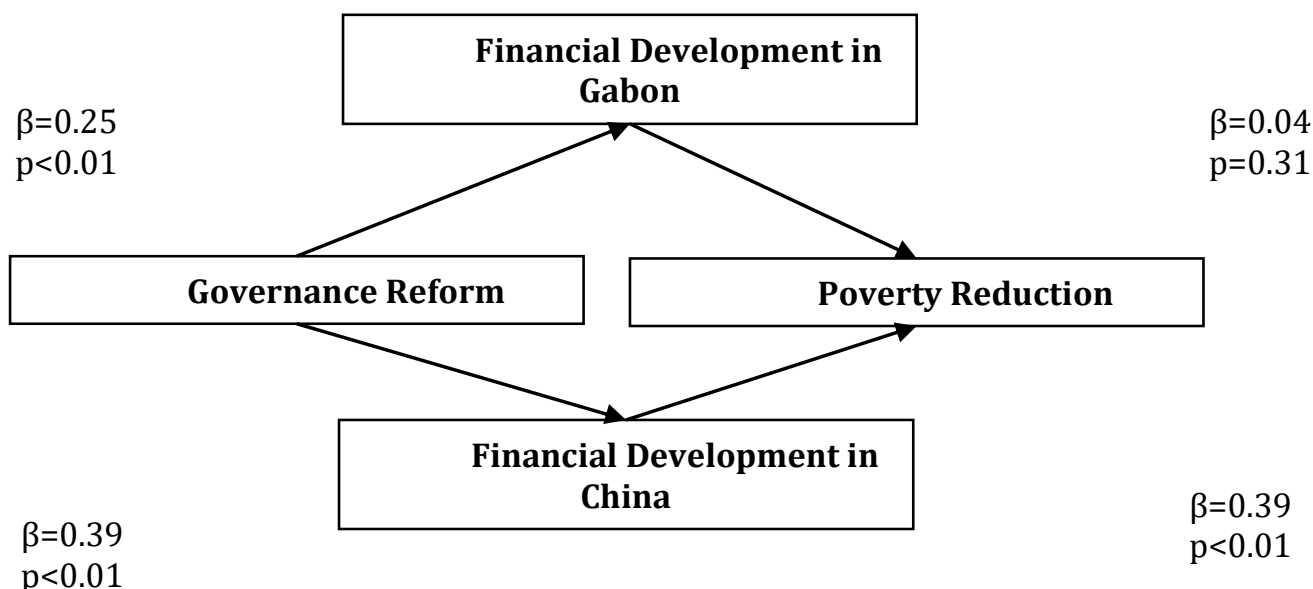

\begin{tabular}{lccccc}
\multicolumn{7}{l}{ Table 4: Hypotheses testing and moderation analysis. } \\
\hline Hypothesis & Effect of & Effect on & $\boldsymbol{\beta}$ & p-value & Results \\
\hline H1a & GR & FDG & .25 & $<0.01$ & Confirmed \\
H1b & GR & FDC & .39 & $<0.01$ & Confirmed \\
H2 & FDG & PR & .04 & $>0.31$ & Rejected \\
H3 & FDG & PR & .39 & $<0.01$ & Confirmed \\
\hline
\end{tabular}

${ }^{*} \mathrm{GR}=$ Governance reform, FDG=Financial development in Gabon, FDC=Financial development in China, $\mathrm{PR}=$ Poverty reduction.

\section{Discussion}

Previous researches on financial sector widely focused on the strategic point of view that considers the financial resource as a technique that enhances cash flow and credit-ability through the use of an inter-organizational approach offered by financial service providers (Hoffman, 2005). Recent literature on financial management, however, has indicated that financial progress and greater access to financial services would greatly contribute to revenue growth and poverty reduction Claeessens and Feijen (2007). Drawing on the background of financial growth and poverty reduction, this study aims to compare poverty reduction rates between China and Gabon through One Belt and Road Project. Nonetheless, this paper is consistent with the Park et al. (2004) research. In some countries, scholars have tried to investigate the connection between the growth of the financial sector and poverty reduction. Therefore, the present study is also in line with Odhiambo earlier work (Odhiambo, 2010a). Using an auto-regressive distributed lag (ARDL)-bound testing the tool, the scholar investigates temporal causal relationship between financial sector growth and poverty reduction. Further studies are also in line with our study, for example,( Hussein 2004) found 
that the financial sector reforms begun in Pakistan in the late 1990s generated a favorable environment significantly. While (Dib et al., 2013) researched how financial development helps in poverty reduction. Accordingly, both governance reform and financial growth were seen in this paper as two crucial approaches to poverty reduction.

\subsection{Theoretical implications}

This paper makes several theoretical contributions. First, it adds to the financial management literature by providing new insights to understand the effects of financial development on the reduction of poverty rates. Second, our study indicates that governance reform would be an advantage for financial development and the reduction of poverty. Finally, our paper argues that government, organizations, and practitioners should take into account the critical role of reform and its significant effect on financial development and poverty reduction. Our study extends the work of Honohan (2004) who found that financial sector development is negatively linked to headcount poverty. This paper also added to the previous literature on financial management by incorporating financial development as a poverty mitigation strategy. Moreover, our empirical findings are consistent with many earlier studies (Stieglitz, 1998; Jillian and Kirkpatrick, 2002). The scholars claimed that financial development can enhance opportunities to access formal finance. Further, our findings are also in line with the earlier study of Geda et al., (2006), they investigated the relationship between financial development and poverty reduction.

\subsection{Managerial implications}

The present study has some relevant and significant implications from a managerial perspective. First, it provides several managerial contributions to practitioners, governments, and organizations. Second, our results will help practitioners or executives alleviate to well manage poverty by implementing effective financial policies in case to reduce poverty. Governments need to learn about different types of reform involved in financial strategies. Reform may produce multiple benefits that greatly impact poverty reduction. Effective policies are critical to significantly reduce poverty (Kakwani,et al, 2008). Third, our study also provides decision-making methods that may help governments to adopt different reform and boost financial development and reduce poverty. In our study reform may help executives of the companies reduce their vicious cycle of poverty and generate higher economic growth. Governance reform thus offers benefits of financial growth and decreases poverty. Despite the relevant contribution to our insights, our findings are subject to various limitations: First, our sample is relatively limited. A future study should expand our sample scale and incorporate a comparative study between China and European countries to capture a greater spread. Second, our study was based on a questionnaire survey in China and the Gabonese context. Since the relationship between governance reform, financial development, and the reduction of poverty may develop as a gradual process; a more appropriate longitudinal study may offer further investigation to look at their possible relationships. Third, our study was based on a cross-sectional research design that may cause common method bias, although we tested this concern and our outcomes did not have such an issue. Fourth, future studies should use further methods to confirm the results of our study. In addition, our study was conducted between China and Gabon, and future studies may employ our current research model to extend-scale organizations. Moreover, we collected our data on two developing countries. In future studies, data may be collected from multiple developing countries. Finally, future studies can also investigate the effects of governance reform on both financial development and the reduction of poverty in the context of developed countries.

\subsection{Limitations and future research}

Given the important contribution of our paper, our results are subject to some limitations.However,our sample is relatively small. Future research should extend our sample size and include a comparative analysis between China and European countries. Future research will also analyze the influence of governance reform on both financial growth and poverty reduction in developing countries. 


\section{Conclusion}

This study compared poverty alleviation between China and Gabon through One Belt and Road Project. The empirical findings of this study indicate that the Chinese-Gabonese characteristics of financial growth and poverty reduction are almost identical. Additionally, the governance reformed that has been going on in China and Gabon for decades is likely to lead in the long term to further growth of the financial sector.

\section{Acknowledgments}

This work has been supported by grants from philosophy and social science research of the Ministry of Education (16JZD025), Science and Technology Innovation Fund of Gansu Agricultural University (GSAU-XKJS-2018-245).

\section{Citation information}

Nguembi, P., Zhang, Y., Abdalla, H. S. (2020). Comparing the reduction of poverty rate between China and Gabon through One Belt and Road Project. Economics, Management and Sustainability, 5(2), 122-131. doi:10.14254/jems.2020.5-2.9

\section{References}

Adhikari, A., Derashid, C., \& Zhang, H., (2006). Public policy, political connections, and effective tax rates: Longitudinal evidence from Malaysia. Journal of Accounting and Public policy, 25(5), 574595.

Akyildiz, I.F., Xie, J., \& Mohanty, S., (2004). A survey of mobility management in next-generation allIP-based wireless systems. IEEE Wireless communications, 11(4), 16-28..

Allen \& Radev, (2006), Managing and controlling extrabudgetary funds, IMF working paper. Armstrong, J.S., Overton, T.S., 1977. Estimating nonresponse bias in mail surveys. J. Mark. Res. 14(3), 396-402. http://dx.doi.org/10.2307/3150783/

Bittencourt, M., (2010). Financial development and inequality: Brazil 1985-1994. Economic Change and Restructuring, 43(2), 113-130.

Burgess, R., \& Pande, R., (2003). Do rural banks matter. Evidence from the Indian social banking experiment. Evidence from the Indian Social Banking Experiment (August 2003), 2.

Cammack, P., (2004). What the World Bank means by poverty reduction, and why it matters. New Political Economy, 9(2), 189-211.

Claessens, S., \& Perotti, E., (2007). Finance and inequality: Channels and evidence. Journal of comparative Economics, 35(4), 748-773.

Chen, H., (2006). Development of financial intermediation and economic growth: The Chinese experience. China Economic Review, 17(4), 347-362.

Dib, Y., Ouali, N.E., \& Tabti, S., (2013). Développement financier, croissance économique et instabilité financière (Doctoral dissertation, Université de bejaia).

Engle, R.F., \& Granger, C.W., (1987). Co-integration and error correction: representation, estimation, and testing. Econometrica: journal of the Econometric Society, 251-276.

Extractive Industries Transparency Initiative/ Initiative pour la Transparence dans les Industries Extractives (EITI/ITIE) 2011. Report for Gabon.

Fornell \& D. F. Larcker, (1981). Structural Equation Models with Unobservable Variables and Measurement Error: Algebra and Statistics. Journal of Marketing Research, 18(3), 382-388. doi:10.2307/3150980.

Franz, D.R., HassabElnaby, H.R., \& Lobo, G.J., (2014). Impact of proximity to debt covenant violation on earnings management. Review of Accounting Studies, 19(1), 473-505. 
Funke, N., Ahmed, F., \& Arezki, R., (2005). The composition of capital flows: Is South Africa different? (No. 5-40). International Monetary Fund.

Gabon, Supreme Audit Institution reports: http://www.ccomptes.ga/index.php/telechargements/catgory.

Gabon Law, (2014) on transparency and good governance for public finance21/2014.

Gabon, Organic law, (2015) on budget law and budget execution20/2014,

Gao, L., (2010). Achievements and challenges: 30 years of housing reforms in the People's Republic of China. Asian Development Bank Economics Working Paper Series, (198).

Geda, A., \& Shimeless, A., (2006). Openness, inequality and poverty in Africa. UN, Department of Economic and Social Affairs.

Hair, J.F., Black, W.C., Babin, B.J., Anderson, R.E. and Tatham, R. (2010). Multivariate Data Analysis, 7th ed., Pearson, New York, NY.

Hofmann, E., (2005). Supply chain finance: some conceptual insights. Beiträge Zu Beschaffung Und Logistik, 203-214.

Honohan, P. (2004). Financial development, growth \& poverty: how close are the links?. In Financial development and economic growth (1-37). Palgrave Macmillan, London.

Hussein, K., (2004). Ethical investment: empirical evidence from FTSE Islamic index. Islamic Economic Studies, 12(1).

IMF. (2016). Corruption: Costs and Mitigating Strategies. Staff Discussion Note 16/05.

IMF. (2016b). Public Financial Management Performance Report - Gabon Public Expenditure and Financial Accountability (PEFA).

IMF. (2017). Formulation of priority actions for tax and customs revenue mobilization, TA report.

Jalilian \& Kirkpatrick. (2002). Financial Development and Poverty Reduction in Developing Countries. International Journal of Finance and Economics, 7(2), 97-108.

Johansen, S., \& Juselius, K. (1990). Maximum likelihood estimation and inference on cointegrationwith appucations to the demand for money. Oxford Bulletin of Economics and statistics, 52(2), 169-210.

Kakwani, N., \& Silber, J. eds., (2008). Quantitative approaches to multidimensional poverty measurement. Springer.

Lee, C.P., Shim, J.P. (2007). An exploratory study of radio frequency identification (RFID) adoption in the healthcare industry. Eur. J. Inf. Syst., 16 (6), 712-724.

Dassah, M.O., (2013). Longitudinal analysis of South Africa's performance on the Mo Ibrahim Index of African Governance. Journal of Public Administration, 48(Special issue 1), 730-750.

Narayan, P.K., \& Smyth, R. (2005). Electricity consumption, employment and real income in Australia evidence from multivariate Granger causality tests. Energy policy, 33(9), 1109-1116.

Odhiambo, N.M. (2009). Electricity consumption and economic growth in South Africa: A trivariate causality test. Energy Economics, 31(5), 635-640.

Odhiambo, N.M. (2010). Energy consumption, prices and economic growth in three SSA countries: A comparative study. Energy policy, 38(5), 2463-2469.

Park, N.K., (2004). A guide to using event study methods in multi-country settings. Strategic Management Journal, 25(7), 655-668.

Podsakoff, P. M., MacKenzie, S. B., Lee, J.-Y., \& Podsakoff, N. P. (2003). Common method biases in behavioral research: A critical review of the literature and recommended remedies. Journal of Applied Psychology, 88(5), 879-903. https://doi.org/10.1037/0021-9010.88.5.879.

Quartey, P. (2005). Innovative ways of making aid effective in Ghana: tied aid versus direct budgetary support. Journal of international development, 17(8), 1077-1092. 
Shahbaz, M. (2009). Financial performance and earnings of poor people: a case study of Pakistan. Journal of Yasar University, 4(16), 2557-2572.

Yuan, J. (2006). Institutional Analyses of Poverty Evolution in Rural China, 1978-2003. Available at SSRN 980049.

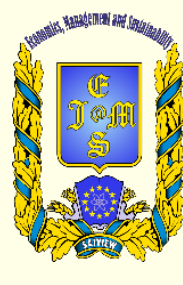

(c) 2016-2020, Economics, Management and Sustainability. All rights reserved.

This open access article is distributed under a Creative Commons Attribution (CC-BY) 4.0 license.

You are free to:

Share - copy and redistribute the material in any medium or format Adapt - remix, transform, and build upon the material for any purpose, even commercially.

The licensor cannot revoke these freedoms as long as you follow the license terms.

Under the following terms:

Attribution - You must give appropriate credit, provide a link to the license, and indicate if changes were made.

Attribution - You must give appropriate credit, provide a link to the license, and indicate if changes were made.
You may do so in any reasonable manner, but not in any way that suggests the licensor endorses you or your use.

No additional restrictions

You may not apply legal terms or technological measures that legally restrict others from doing anything the license permits.

Economics, Management and Sustainability (ISSN: 2520-6303) is published by Scientific Publishing House "CSR",

Poland, EU and Scientific Publishing House "SciView", Poland

Publishing with JEMS ensures:

- Immediate, universal access to your article on publication

- High visibility and discoverability via the JEMS website

- Rapid publication

- Guaranteed legacy preservation of your article

- Discounts and waivers for authors in developing regions

Submit your manuscript to a JEMS at http://jems.sciview.net or submit.jems@sciview.net 